\title{
AKSESIBILITAS PIMPINAN DALAM MEWUJUDKAN KINERJA ORGANISASI PUBLIK
}

\author{
Oleh \\ Rosidah \\ FISE UNY
}

\section{Abstrak}

Organisasi publik sudah saatnya menjadi perhatian para pemimpin untuk diberdayakan dalam rangka meningkatkan pelayanan publik. Dalam mewujudkan kinerja organisasi publik maka peran pemimpin sangat substansial untuk menentukan segala kebijakan dan implementasinya serta dalam menciptakan lingkungan yang kondusif. Berbagai terobosan perlu dilakukannya, mulai dari perubahan struktural, aspek ketrampilan dalam pemahaman kerjasama internal dengan para bawahanya maupun eksternal yakni dengan pihak lembaga swasta, para stakeholder. Di samping itu perlu memahami dan melakukan integrative culture dan berbagai transformasi nilai yang harus dilakukan untuk pengembangan organisasi serta mengantisipasi lingkungan yang berkembang. Yang tidak kalah penting adalah pemahaman adanya akuntabilitas moral/mental yang melekat pada diri seorang pimpinan.

Kata Kunci : aksesibilitas kepemimpinan, kinerja organisasi

\section{Pendahuluan}

Keberhasilan sebuah organisasi tidak lepas dari eksistensi pimpinan. Pimpinan merupakan seorang yang mempunyai tanggung jawab dalam menjalankan dan mengimplementasikan kebijakan-kebijkan yang telah dibuat/menjadi sebuah keputusan dalam organisasi. la mempunyai kekuasaan yang luas untuk menentukan segala kebijakan yang harus dijalankan dalam rangka pencapaian tujuan. Pemimpin mempunyai wewenang penuh untuk mengarahkan kegiatan para anggotanya, namun anggota tidak mempunyai power untuk mengarahkan kepemimpinan secara langsung. Johnn Kotter berpendapat bahwa kepemimpinan yang kuat dan manajemen yang kuat penting untuk keefektifan organisasi secara optimal. 
Anggota organisasi memberikan kontribusi dalam menentukan kedudukan kepemimpinan, mem-buat proses kepemimpinan berjalan sesuai dengan misi dan mereka ju-ga mempunyai kontribusi terhadap pembentukan kualitas kepemimpinan. Perilaku pemimpin yang efektif antara lain tergantung pada tindakan para pengikutnya, apakah menerima baik atau menolak pimpinannya tanpa mempedulikan apa yang menjadi kebijakannya. Ada hubungan yang signifykan antara pola perilaku kepemimpinan dengan kinerja kelompok/anggota organisasi. Sehingga Pimpinan harus memahami satrategi peningkatan kinerja. dan implementtasi kinerja yang mampu menegakaan disiplin pada hal-hal yang sudah menjadi komitmen bersama.

Dalam teori/konsep kepemimpinan banyak gaya-gaya kepemimpinan yang dapat dipakai sebagai acuhan dalam melakukan tugas kepemimpinan. Seorang yar.g ingin berhasil dalam kepemimpinannya harus mempelajari berbagai gaya-gaya tersebut, yang nantinya mampu memberikan pencerahan atau sebagai pertimbangan dalam memperilakukan bawahan-nya atau menentukan alternatif kebijakan yang tepat sesuai dengan tujuan. Perubahan situasi bawahan dan kondisi sosial, politik, ekonomi, kebijakan yang mendukung harus dicermati dalam rangka menentukan perilaku kepemimpinannya. Seorang pemimpin yang mampu menyesuaikan gaya kepemimpinannya cenderung berhasil dalam mengelola organisasinya. Gaya kepemimpinan seseorang akan mempengaruhi dan menentukan dalam manajemen organisasinya. Sebagaimana dikatakan oleh Daniel Goleman bahwa" Para eksekutif yang paling efektif menggunakan sekumpulan gaya memimpin yang berbeda-beda, setiap gaya digunakan pada takaran dan waktu yang tepat. jika dilakukan akan membawa hasil yang baik. Dan yang lebih baik lagi, gaya dapat dipelajari." Untuk mengetahui sejauhmana aksesibilitas kepemimpinan dalam membangun kinerja organisasi selanjutnya akan dibahas secara mendasar pada tulisan selanjutnya.

\section{Urgensi Kinerja Organisasi Publik}

Kinerja merupakan tampilan hasil kerja, yakni merupakan state of condition dari suatu pelaksanaan kerja dalam mencapai sesuatu yang diinginkan. Kinerja organisasi merupakan gambaran unjuk kerja oganisasi dalam mencapai tujuan atau sasaran. Dalam kinerja tersebut juga dapat dilihat berbagai ukuran keberhasilan target atau tingkat capaian kinerja yang diukur dengan indikator kinerja, yang kesemuanya harus menjadi tanggungjawab seluruh jajaran organisasi. Indikator tersebut harus memenuhi 
kriteria SMART (surable, attainable, realistic, time-frame). Untuk itu dibutuhkan aksessibilitas pimpinan dalam mewujudkan kinerja organisasi.serta komitmen yang tinggi dari pimpinan serta didukung oleh semua unit/-kelompok anggota yang ada didalamnya.

Dengan adanya penilaian terhadap kinerja organisasi maka manfaat yang dapat diperoleh, antara lain:

1. Membantu pimpinan dalam penentuan tingkat pencapaian tujuan yang perlu dicapai.

2. Penilaian kinerja yang efektif memberi umpan balik bagi pengelola dan pembuat keputusan dalam proses evaluasi dan tindak lanjut,

3. Menjadi alat evaluasi bagi pimpinan, stakeholder dan para pegawai.

4. Mengidentifikasi kualitas pelayanan instansi pemerintah.

Keberhasilan kinerja organısasi diawali dengan sejauhmana kualitas kinerja para pegawainya. Kinerja organisasi akan baik, yang hal tersebut banyak ditentukan oleh proses kepemimpinannya. Kalau menginginkan proses kepemimpinan yang berhasil, dengan kata lain kinerja organisasai baik maka perlu menegakkan dan mewujudkan kinerja ma-sing-masing pegawai. Evaluasi terhadap kinerja diawali dari perencanaan kinerja. Perencanaan kinerja ( performance appraisal) digambarkan ketika menentukan rencana strategik (renstra) dan selanjutnya akan diintegrasikan dalam proses pengganggaran. Untuk kepentingan akuntabilitas maka perencanaan kinerja berfungsi melihat kembali apakah organisasi tersebut dapat melaksanakan delegasi wewenang dan pelaksanaan tugas yang dilimpahkan oleh bawahannya. Di samping itu juga dapat mengukur sejauhmana target-target yang telah ditentukan dapat tercapai.

Perencanaan kinerja merupakan bagian dari fungsi manajemen untuk meningkatkan kinerja yang mengutamakan tingkat analisis tinggi dalam upaya menentukan target yang realistis. Tahapan dimulai dari perencanaan kinerja dan berakhir pada evaluasi kinerja. Manfaat adanya manajemen kinerja sebagaimana diterangkan dalam Modul Sistem Akuntabilitaas Kinerja Instansi Pemerintah (2004:5758) antara lain:

1. Mendukung supaya mengembangkan budaya kerja dan mengubah cara berpikir agar berorientasi pada proses dan hasil kerja.

2. Mengikat unit kerja atau pegawai terkait untuk melaksanakan fungsi-fungsi supaya teratur.

3. Mempermudah identifikasi tahapan-tahapan mana yang lemah dan harus diperbaiki.

4. Menghindari penumpuk-kan pekerjaan pada satu taha- 
pan tertentu, yang memungkinkan terjadinya rekayasa rencana dan realisasi sasaran/target kinerja.

Ada beberapa persyaratan sebelum menentukan rencana, yakni bahwa menurut pandangan Faizal Basri (2005) seluruh anggota organisasi perlu:

1. Komitmen dan dukungan dari pucuk pimpinan terutama direktur pelaksana dan ketua dalam keseluruhan proses.

2. Komitmen untuk menjalankan peran-peran dan harapan-harapan bagi semua peserta dalam proses perencanan, termasuk kejelasan mengenai siapa yang akan menyumbangkan masukan pada rencana itu dan siapa yàng akan membuat keputusan ảkhir.

3. Komitmen teguh untuk mengumpulklan dan menggunakan informa-si yang relevan untuk menilai program yang ada sekarang dan mengevaluasi bagaimana caranya memenuhi kebutuhan klien sekarang dan mása depan

4. Kerelaan untuk bersikap inklusif dan mendorong partisipasi luas sehingga orang merasa ikut memiliki dan menjadi bersemangat berkat proses itu.

Untuk memahami hal di atas maka pimpinan perlu untuk mensosia- lisasikan berbagai komitmen yang harus menjadi milik bersama dan per-lu dijalankan dalam proses penye-lenggarraan kerja. Dalam upaya membangun kinerja organisasi transformasi nilai-nilai perlu dikembangkan dalam rangka memenuhi tuntutan perkembangan publik baik internal maupun eksternal, yang sedang berlangsung. Kepemimpinan mempunyai keterkaitan dengan nilai-nilai dan strategi organisasi. Nilai-nilai yang dikembangkan dalam konsep Good Goverment, misalnya, berbeda dengan kepemimpinan birokratis, yang antara lain menganut konep: hierarkhis, sentralis, komunikasi satu arah. Menurut konsep yang diciptakan oleh USAID diterangkan Suripto dalam pengembangan institusi, sebagaimana ditulis dalam makalahnya:. "Transformasi Kepemimpinan Birokratis menuju Kepemimpinan Modern yang Ramah terhadap Prinsip-prinsip dan Nilainilai Good Goverment" bahwa untuk kepentingan pemda di Indonesia mempunyai prinsip-prinsip dasar"

1, Prinsip efektivitas, indicatornya: sumber-sumber pandapatan pemda, perkiraan transfer dalam anggaran pemda, survai kepuasan/ pengaduan konsumen dan adanya pernyataan visi dan misi. 
2. Prinsip keadilan, indikatornya: hak dasar warga negara, wanita pada posisi kunci pemda, kerangka hukum ba-gi kesetaraan gender, kebija-kan kebijakan yang memihak kaum miskin, dan insentif bagi usaha informal.

3. Prinsip partisipasai, indicatornya: kehadiran para pemilih, dan partisipasi menurut jenis kelamin, forurn publik, kepasitas warga untuk terlibat dengan pengambilan keputusan pemda dan kesadaran masyarakat akan isu-isu pemerintahan dan publik.

4. Prinsip akuntabilitas, indicatornya: tinjauan publik, publickasi resmi tentang tender,/kuntrak/ anggaran/rekening, kode etik dan audit indenpenden.

5. Prinsip transparansi, indicatornya: mekanisme bagi pengaduan, kampanye anti korupsi dan pengungkapan pendapatan/aset.

Selanjutnya menurut UNDP, seperti dijelaskan dalam Modul Sistem Akuntabilitas Kinerja Instansi Pemerintah (2004) bahwa ada lima karakter yang harus diperhatikan untuk menuju sistem penyelenggaraan yang baik, yaitu:

1. Interaction (interaksi), melibatkan tiga mitra besar yakni pemerintah, faktor swasta dan masyarakat madani untuk melaksanakan pengelolaan sumber daya ekonomi, sosial dan praktik.

2. Communication (komunikasi), yang di dalamnya terdapat beragam sistem jejaring dalam proses pengelolaan dan kontribusi terhadap kualitas hasil.

3. Self Enforcing Proces (proses penguatan sendiri), sistem pengelolan mandiri adalah kunci keberadaan dan kelangsungan keteraturan dari berbagai situasi kekacauan yang dilsebabkan oleh dinamika dan perubahan lingkungan, memberikan kontribusi terhadap partisipasi dan menggalakkan kemandirian masyarakat dan memberikan kesempatan untuk kreativitas dan stabilitas untuk berbagai aspek kepemerintahan yang baik.

4. Dynamic (dinamis) dalam arti ada keseimbangan dari berbagai unsur kekuatan yang kompleks, yang membuahkan persatuan, harmoni dan kerjasama untuk pertumbuhan dan pembangunan keberlanjutan, kedamaian dan keadilan serta kesempatan merata untuk semua sektor dalam masyarakat madani. 
5. Dynamic interdepence (saling ketergantungan yang dinamis) antara pe-merintah, kekuatan pa-sar dan masyarakat ma-dani.

Dalam impelementasinya li-ma point di atas tergambarkan pa-da proses pengambilan keputusan yang melibatkan pihak stakeholder, dengan menerapkan prinsipprinsip/nilai-nilai good governance, antara lain adanya partisipasi, transparansi, akuntabilitas, dan lainlain sebagaimana diterangkan di atas.

Nilai-nilai yang diyakini akan menjadi pedoman perilaku organisasional Sebuah organisasi yang tidak sehat dapat dilihat dari perilaku masing-masing anggotanya. Unsur kepemimpinan dan sumber daya yàng ada dalam proses organisasi merupakan ińtegrasi dari nilai-nilai good governance serta permujudan lima karakter dari sistem penyelenggaraan, yakni: komunikasi, dunamis, interaksi, proses penguatan sendiri, saling ketergantungan yang dinamis.

Gejala perilaku yang menyimpang atau tidak mendukung kinerja yang baik berpoterisi memicu adanya krisis, dapat dilihat apakah ada kesenjangan antara tujuan/kepentingan dan nilai-nilai organisasi yang dimiliki. oleh pimpinan dengan anak buahnya. Sehingga pada dasamya berkembang atau maju mundurnya serta keberhasilan sebuah organisasi perlu keterbukaan adanya atau tidaknya kesenjangan yang dirasakan antar dan inter pimpinan dengan anggotanya.

Untuk menentukan tingkat ki-nerja yang diinginkan perlu menentukan kebijakan instansi, dengan cara menentukan strategi pedoman dasar pencapaian tujuan dan sasa-ran organisasi. Dalam hal ini diper-lukan persepsi yang sama dengan penekanan khusus pada bentuk kebijakan. Kebijakan tersebut diten-tukan oleh pimpinan puncak orga-nisasi. Adapun yang dimaksud kebijakan dalam hal ini meliputi:

a. Menentukan secara teliti tentang bagaimana stra-tegi akan dilaksanakan, dengan bahasa lain kebijakan merupakan pedoman pelaksanaan tindakan.

b. Mengatur mekanisme tindakan lanjutan untuk pelaksanaan pencapaian tujuan/sasaran.

c. Mengarahkan pada kondisikondisi bahwa setiap pejabat dan pelaksanan di organisasi mengetahui tentang apakah mereka memperoleh dukungan untuk bekerja dan mengimplementasikan keputusan.

Selanjutnya dari kebijakan yang telah disusun maka masingmasing pejabat perlu:

1. Ada dukungan untuk mengimplementasikan kebija- 
kan tersebut dan perlu dibuatkan sebuah programprogram terteniu,

2. Merencanaan Kinerja. Perencanaan. Untuk menetapkan kinerja perlu mengutamakan tingkat analisis tinggi dalam upaya menentukan target yang reaiistis,

3. Setelah melakukan perencanaan kinerja, tahap berkutnya adalah identifikasi hasil yang hendak dicapai dalam penataan program dan pengembangan performance measurement system atau dikenal outcome,

4. Menentukan Indikator Kinerja. Hal-hal yang perlu diperhatikan dalam penentuan indikator kinerja, antara lain: a) terkait dengan tujuar, bj menggambarkan hasil, c) menfokuskan pada hal penting/utama, d) terkait dengan pertanggungjawaban dalam organisasi, e) mengambarkan outcome. Dalam menetapkan indikator kinerja perlu melihat pengalaman masa lalu baik dari organisasinya sendiri maupun organisasi lembaga lain. Lembaga lain dapat dipakai untuk melakukan benchmarking sebagai bahan pertimbangan. Untuk kepentingan tersebut maka data kirerja sangat berarti bagi perencanaan selanjutnya
5. Setelah membuat indikator ki-nerja, tahap berikutnya adalah. menetapkan target yang ingin dicapai.

\section{Transformasi Eksistensi Kepe- mimpinan}

Sebagimana tersirat di atas bahwa keberhasilan organisasi publik pada umumnya dapat memobilisasi sumber daya serta kemampuan pemimpin dalam menciptakan dan dan mengembangkan visi, misi, nilai-nilai dan strategi organisasinya yang sesuai dengan tuntutan lingkungan internal maupun eksternal. Kepemimpinan pada dasarnya tidak mengacu kepada individu dalam struktur kepemimpinan puncak. Kepemimpinan dilihat pada realittas dalam organisai dan diartikan sebagai kolektivitas. Dalam hal tersebut maka definisi kepemimpinan yakni bahwa pemimpin dalam organisasi mempunyai peran substansial dalam membangun kinerja organisasi.

Pemimpin, yang mempunyai legitimate power dan didukung oleh anak buahnya mempunyai kekuatan untuk mengembangkan dan menentukan segala kebijakan yang terjadi dalam organisasinya. Setidaknya ada dua model kepemimpinan: 1) trait theory, 2) behavioral theory. Oleh Arthur Shiriberg cs, (2002) diterangkan bahwa pemimpin adalah orang yang mampu memimpin orang lain, agar ada ke- 
mampuan tersebut maka menurut trait theory, pimpinan harus:

1. Physical vitality uin stamina

2. Intellegence and action oriented judgement

3. Eagerness to accept responsibility

4. Task competen ce

5. Understanding of follower and their needs

6. Skill in dealing with people

7. Need for achievement

8. Capasity to motivate people

9. Courage and resolution.

10. Trustworthiness

11. Decisiveness

12. Self-confidence

13. Assertiveness

14. Adabtabilityfflexibility

Model di atas mengingatkan kapada perilaku organisasional yang harus dímiliki dan diimplementasikar dalam kepemimpinan.. Sering dalam kinerja organisasi, kepemimpinan cenderung hanya berorientasi pada apa yang ingin dicapai dari aspek pekerjan kurang perhatian pada unsur kebutuhan ketrampilan yang harus dimiliki pemimpin ketika berhubungan dengan pa-ra pegawainya. Keperiimpinan organisasi publik diharapkan juga mampu bekerja pada organisasi yang dipimpinnya dan lingkungan yang mempengaruhi. Lebih jauh bahwa dalam kondisi globalisasai dan era good governance pengaruh lingkungan eksternal sangat perlu untuk diperhatikan. Pengaruh lingkungan eksternal, yang meliputi bermacammacam jenis stake holder, missalnya: masyarakat pengguna layanan, pelanggan, komunitas tertentu dalam kemitraan pemerintah) akan sangat susah untuk dipenuhi harapan-harapannya. Sehingga dibutuhkan transformasi kepemimpinan, yang oleh Samodra Wibawa dalam makalahnya: "Kualitas Baru Kepemimpinan: Sebuah Penilaian" dirumuskan bahwa kualitas baru tersebut meliputi:

1. Dari implementator menjadi fasilitator

2. Dari monopoli kekuasaan menjadi berkompetisi dalam melayani publik

3. Dari menunggu petunjuk menjadi berkreasi dan berjiwa wirausaha

4. Dari hanya membelanjakan sumberdaya publik menjadi mendapatkan hasil

5. Dari problem solver menjadi anatisipatory

6. Dari sekedar melayani menjadi memberdayakan masyarakat

7. Dari sentralistis menjadi desentralistis.

Seperti sudah disadari bersama bahwa Reformasi Administrasi sudah mengemuka dalam perjalanan birokrasi publik. Namun perubahan yang terjadi pada umumnya hanya dalam aspek struktural sehingga kurang memberikan hasil yang optimal dalam ki- 
nerja organisasi publik. Perubahan struktural harus selaras dengan perubahan pada kinerja (performances). Dalam hal ini perlu diciptakan integratif culture (Ratminto \& Atik, 2005) yakni setiap orang harus mempunyai perhatian baik terhadap orang maupun kinerka organisasi. Selanjutnya berdasar pada pemikiran Riggs, yang dikutip oleh Ambar Teguh Sulistiyani dalam makalahnya "Mengawal Refor-masi Kultural Organisasi Publik dari Sudut Pandang Kepemimpinan" bah-wa reformasi administrasi meliputi perubahan struktural dan kinerja, untuk itu perubahan tidak cukup pada restrukturisasi akan tetapi sampai pada masalah kultural. Perubahan pada aspek kultural dari sisi pimpinan menekankan pada perilaku. Hal tersebut dikatakan olehnya karena mendasarkan bahwa aspek budaya sangat erat dengan perilaku pemimpin.

Bagaimana format perilaku pemimpin yang seharusnya dijalankan dalami rangka mengoptimalkan kinerja organisasi publik, salah satunya akan sangat dipengaruhi oleh sisitem akuntabilitas. Menurut Sulistiyani \& Aisyah, 1988 yang dikutip oleh Ambar Teguh Sulistiyani masih dalam makalah yang sama sebagaimana di atas bahwa akuntabilitas meliputi: akuntabilitas administratif, akuntabilitas hukum, akuntabilitas publik dan akuntabilitas moral. Dengan akuntabilitas yang kompleks di atas, seorang pemimpin harus menyadarinya bahwa kepemimpinan akan dipertanggungjawabkan tidak saja pada manusia yang ada di bumi ini namun juga bagaimana dia mempertanggungjawabkan kepada Sang Pencipta, ya-itu Tuhannya. Sisi moral penting untuk ditekankan karena upaya apapun kalau tidak didasari nilainilai moral atau kesadaran moral maka segala-nya akan mudah dilakukan dengan berbagai argumentasi meskipun kebenaran yang hakiki hanya ada satu.

\section{Penutup}

Untuk mewujudkan kinerja organisasi publik perlu ada upaya yang sungguh-sungguh dari seluruh pegawai pemerintahan baik dari unsur pimpinan maupun bawahanya. Namun demikian aksesibilitas pimpinan dalam hal ini menjadi noer satu (unsur yang menentukan) karena dia yang mempunyai legitiasi power untuk menentukan seluuh kebijakan dalam proses organiasi. Banyak konsep kepemimpinan yang harus dipelajari oleh piminan dalam membentuk kinerja pemeintahan yang baik, antara lain adaya perencanaan kinerja, identifikasi hasil yang ingin dicapai, indikator kinerja serta target yang harus dicapai. Di samping itu perlu memerhatikan nilai-nilai good goverance, yang perlu diterapkan. Dalam pengembangannya maka aspek moral/mental atau akutabilitas moal perlu diagendakan dalam mene- 
apkan sistem akuintabilitas yang ada. Sehingga untuk melakukan itu semua maka seorang pemimpin nampaknya perlu memahami dan memaknai berbagai transformasi nilai yang harus dilakukan untuk pengembangan mengantisipasi organisasi serta berkembang dalam era global..

\section{Daftar Pustaka}

Arthur Shriberg, David Lshriberg, Carol Lloyd, 2002. Prac-ticing Leadership, Principles and Applications. New Ca-ledonia: Pine Three Compo-sition, Inc.

Kotter John P., 2001. What Leaders Really Do, Kepemimpinan dan Perubahan, Jakarta: Erlangga.
Ratminto \& Atik Septi Winarsih, $2005 . \quad$ Manajemen Pelayanan Yogyakarta: Pustaka Pela-jar.

Modul Sistem Akuntabilitas Kinerja Instansi Pemerintah, 2004. LAN Republik Indonesia.

\section{Biodata Penulis}

Rosidah, M.Si adalah salah satu Dosen Pengajar pada Program Studi Pendidikan Administrasi Perkantoran FISE- UNY 